\title{
Marià CORBI, Hacia una espiritualidad laica, sin creencias, sin religiones, sin dioses
}

Barcelona, Ed. Herder, 2007, 350 p.

\section{Lili Castella}

\section{CpenEdition}

\section{Journals}

Édition électronique

URL : http://journals.openedition.org/assr/21551

DOI : 10.4000/assr.21551

ISSN : $1777-5825$

Éditeur

Éditions de l'EHESS

Édition imprimée

Date de publication : 31 décembre 2009

ISBN : 978-2-7132-2218-4

ISSN : 0335-5985

\section{Référence électronique}

Lili Castella, « Marià conBı, Hacia una espiritualidad laica, sin creencias, sin religiones, sin dioses », Archives de sciences sociales des religions [En ligne], 148 | octobre-décembre 2009, document 148-35, mis en ligne le 15 novembre 2012, consulté le 21 septembre 2020. URL : http:// journals.openedition.org/assr/21551; DOI : https://doi.org/10.4000/assr.21551 


\title{
Marià CORBI, Hacia una espiritualidad laica, sin creencias, sin religiones, sin dioses
}

Barcelona, Ed. Herder, 2007, 350 p.

\author{
Lili Castella
}

\section{RÉFÉRENCE}

Marià CORBI, Hacia una espiritualidad laica, sin creencias, sin religiones, sin dioses, Barcelona, Ed. Herder, 2007, 350 p.

148-35

1 En la introducción el autor plantea el punto de partida de su trabajo: la sociedad que nos ha tocado vivir padece una de las mutaciones más profundas de la historia humana, pasar de vivir haciendo lo mismo y configurando el presente y el futuro con patrones del pasado, propio de sociedades preindustriales, a vivir habiéndose de mover continuamente. La nueva sociedad, que la llamaremos sociedad del conocimiento y de innovación constante, modifica continuamente la forma de pensar, sentir, organizarse y vivir de los individuos y grupos que no pueden quedar fijados por ningún tipo de creencias ni normas del pasado porque les impediría el movimiento.

2 El autor propone comprender el tipo de repercusiones y el alcance que el mismo conlleva en el ámbito axiológico. Empieza estudiando como se estructuraba el mundo valoral en las sociedades preindustriales. Concluye que en ellas fueron los mitos los que daban las coordenadas axiológicas a los individuos y a los grupos. Su poder como estructuradores axiológicos proviene de su estructura profunda derivada de la actividad con la que sobrevive el grupo -la caza, la recolección, el cultivo, etc. De esta acción principal saldrá la metáfora central que configura el núcleo del mito y a través de él modelará la interpretación y la valoración del mundo en los individuos. Cambios 
en la forma de sobrevivir de los grupos, implican cambios en los mitos y por tanto cambios en la interpretación y valoración de la realidad.

En la primera industrialización el mito -de lenguaje simbólico- propio de las sociedades agrarias-autoritarias es sustituido, poco a poco, por las ideologías -de lenguaje filosófico-, mejor adaptadas al saber técnico de los ingenieros que asumirán la función de programación axiológica.

4 Con la segunda industrialización se implanta un nuevo sistema de producción de bienes y servicios basado en la producción de conocimientos y tecnología. La innovación científica y tecnológica suponen transformaciones en el trabajo, que comportan cambios en la organización laboral que, consecuentemente, implican innovaciones en las relaciones y en las finalidades colectivas que suponen cambios en los sistemas de cohesión y valoración de los grupos, es decir, cambios axiológicos. Ahora todo se mueve, por tanto las creencias religiosas (mitológicas) y laicas (ideologías), que son formas fijadas de interpretación, no se podrán mantener, porque resultan contraproducentes para la marcha de la sociedad. Consecuentemente será el fin de la religión.

5 En esta situación es necesario plantearse y resolver cómo cultivar aquello que antes venía bajo formas religiosas: la dimensión absoluta de la existencia. La base para poder hablar de una dimensión absoluta de la realidad el autor la sitúa en la habilidad humana del habla. Por ella los humanos pueden adaptarse a los cambios más rápidamente que el resto de especies que necesitan modificaciones genéticas que requieren millones de años. Los cambios en los modos de sobrevivencia la especie humana los afronta con los cambios de cultura.

6 El habla posibilita poder distinguir entre lo que es el significado de las realidades para nosotros, y aquello que son las coses en ellas mismas. Nuestro un mundo es ternario: sujetos, objetos y habla, por lo cual los humanos tenemos una doble experiencia de la realidad: una en función de nuestras necesidades -como los demás animales-, y otra no relativa a ellas. Esta segunda experiencia, no condicionada por la necesidad, nos aporta una noticia de la realidad en ella misma, independientemente de la significación que pueda tener para los individuos. En este sentido será experiencia absoluta.

7 El acceso a la dimensión absoluta de la realidad, lo que nuestros antepasados llamaron espiritualidad, derivada de nuestra condición de hablantes tendrá que considerarse como "la cualidad humana específica". Esta nuestra condición humana permite que podamos distanciarnos del mundo condicionado, creado por nuestra condición de animales necesitados; un mundo irremediablemente egocéntrico. Este distanciamiento es fuente de flexibilidad, y su cultivo será un valor para la sociedad dinámica. Así el autor concluirá que es necesario que la sociedad de innovación se plantee el cultivo de la cualidad específicamente humana, la doble experiencia de la realidad, por una doble razón por una doble razón: la primera, porque ahora más que nunca se necesitan individuos de cualidad para conducir los cambios a los que están sometidos los individuos, los grupos y el planeta mismo; la cualidad humana es fuente de flexibilidad, condición indispensable para desarrollar la creatividad imprescindible para las sociedad de innovación y cambio, la segunda razón: el cultivo de la dimensión absoluta de lo real vale por sí misma.

8 Hoy es preciso plantearse formas de cultivo de la cualidad humana que no sean religiosas porque ya no resultan hábiles; pero el autor advierte que seria arriesgado y con desperdicio de riquezas no aprender del legado de cualidad humana y cualidad 
humana profunda que la historia nos ha transmitido a través de las tradiciones religiosas de la historia de la humanidad.

9 Este libro es la recopilación de un estudio de más de cuarenta años. Resulta novedoso que a partir de la lingüística y la antropología sitúe la espiritualidad como parte misma de la naturaleza humana. Prefiere sustituir el término "espiritualidad" por el de "cualidad humana", porque "espiritualidad" hace referencia a una antropología de cuerpo y espíritu que ya no es la nuestra. El autor plantea la imperiosa necesidad del cultivo de la cualidad humana en un mundo en que el hombre es responsable de su destino y del destino de la vida en el planeta. 